\title{
Sublingual Immunotherapy with Quantified Peach Extract: An Alternative Treatment in Legumes Allergy
}

\section{Antonio Letrán ${ }^{\star}$, Marisa Espinazo and Francisco Moreno}

Clínica Dr Lobatón, Cádiz, Spain

*Corresponding author: Antonio Letrán, Clínica Dr Lobatón, AvenidaFernándezLadreda, No.9, 11008Cadiz, Spain, Tel: 956292100; Fax: 956260214; E-mail: a_letran@yahoo.es

Rec date: 10 Jan 2014; Acc date: 19 Feb 2014; Pub date: 23 Feb 2014

Copyright: (C) 2014 Letrán A, et al. This is an open-access article distributed under the terms of the Creative Commons Attribution License, which permits unrestricted use, distribution, and reproduction in any medium, provided the original author and source are credited.

\section{Short Communication}

The legume family plays a fundamental role in human nutrition as a substantial protein source. In the countries where they are widely consumed (Mediterranean area), legumes are one of the most common foods causing allergic reactions particularly in children [1]. It has been documented that seed storage proteins represent major allergens of legumes [2], but recent studies have strengthened the paper of Lipid Transfer Proteins (LTP) as novel legume allergens whose sensitization is directly linked to adult peanut allergy in our country $[3,4]$.

We report a 34-year-old man with a previous history of well controlled mild persistent allergic rhinitis and asthma due to house dust mites and olive pollen sensitizations. He presented three episodes of generalized rash with facial angioedema, cough, upper dyspnea and syncope immediately (15-30 minutes of latency) after the ingestion of lentil, chickpea and walnut. No coincidental cofactors like exercise or non-steroid anti-inflammatory drugs intake were associated. Intramuscular adrenaline was necessary to resolve the reactions. Curiously he mentioned he did not eat fruit; since the avoidance of all legumes and nuts no new similar adverse episode has occurred.

Skin prick tests (SPT) with a commercial battery of common inhalants (Bial-Aristegui, Bilbao. Spain) were only positive to
Dermatophagoides Pteronyssinus, Dermatophagoides Farinae and Olea europea pollen. SPT with Profilin (palm) was negative and Pru p3 (peach peel) was positive; both extracts were obtained from ALKAbello (Madrid, Spain). Prick by prick with legumes and nuts were positive to lentil, pea, chickpea, bean, soy, almond, sunflower seed, peanut, pistachio, walnut, hazelnut, cashew and chestnut. Specific Ig E determination to allergenic components was performed using microarray platform ImmunoCAP-ISAC 112 (Thermoscientific, Upsala, Sweden). It revealed moderate-high levels of specific IgE against mostly all the LTP arrays: rAra h9: 2.4 ISU, rCor a8: 3.8 ISU, nJug r3: 4.7 ISU, rPru p3: 3.7 ISU, nArt v3: 4.2 ISU, nOle e7: 3.2 ISU and rPla a3: 1.9 ISU. Component study with storage proteins, Profilins, PR-10s and Polcalcins were negative. All these results are summarized in Table 1 . Due to the severity of the reactions we did not make an open challenge test with implicated food.

But the patient expressed his active desire to eat legumes, soPru p3 quantified peach sublingual immunotherapy extract (SLIT-peach, ALK-Abello, Madrid, Spain) was prescribed. Following standard recommendations a four vials $(0.05,0.5,5$ and $50 \mu \mathrm{g} / \mathrm{ml}$ of Pru p3Peach peel LTP) and days rush schedule was applied. From an initial dose of $0.242 \mu \mathrm{g}$ of Pru p3 the first day, the maintenance dose consisted of $10 \mu \mathrm{g}$ of Pru p3 everyday [5].

\begin{tabular}{|l|l|l|l|l|l|}
\hline & Skin prick test & $\begin{array}{l}\text { LTP } \\
\text { specific Ig E }\end{array}$ & Storage proteins specific Ig E & $\begin{array}{l}\text { Profilin } \\
\text { specific Ig E }\end{array}$ & $\begin{array}{l}\text { PR-10 } \\
\text { specific Ig E }\end{array}$ \\
\hline Peach & Positive & 3.7 ISU & - & - & $<0.3$ ISU \\
\hline Palm Profilin & Negative & - & - & - & - \\
\hline Lentil & Positive & - & - & - & - \\
\hline Soy & Positive & - & $<0.3$ ISU & - & $<0.3$ ISU \\
\hline Peanut & Positive & 2.4 ISU & $<0.3$ ISU & - & $<0.3$ ISU \\
\hline Hazelnut & Positive & 3.8 ISU & $<0.3$ ISU & - & $<0.3$ ISU \\
\hline Walnut & Positive & 4.7 ISU & $<0.3$ ISU & - & - \\
\hline Cashew & Positive & - & - & - & $<0.3$ ISU \\
\hline Olive pollen & Positive & 3.2 ISU & - & - & - \\
\hline Birch pollen & - & - & - & $<0.3$ ISU & $<0.3$ ISU \\
\hline
\end{tabular}

Table 1: Skin prick test and ImmunoCAP-ISAC results

Immunotherapy was maintained for four months with good tolerance, the only relevant secondary effect was light oral pruritus with the first doses, which was solved with antihistamines. Subsequently we undertook an open oral challenge with lentil and 
chickpea. We used lentil and chickpea soups in progressively increasing doses $(1,5,10,30,75$, and $125 \mathrm{~mL})$ every 15 minutes according to previous studies [6]. Both challenges were negative. Oral challenge with nuts was not performed due to patient refusal.

Consistent with published data, LTP syndrome could include a complex clinical manifestation associated with a large group of taxonomically unrelated food [7]. Our patient suffered anaphylactic reactions principally after the ingestion of legumes, but he presented positive SPT to almost all legumes and nuts. Storage proteins were expected to be the causal allergens especially considering the low LTPs sensitization previously described in our influence area [8]. Nevertheless component resolved diagnosis demonstrated a high and exclusive LTPs sensitization establishing specific IgE recombinant techniques as a fundamental tool for unmasking complicated sensitizations in the search for the primary allergen.

It has been demonstrated allergen sublingual immunotherapy increases allergen tolerance via reorientation of allergen-specificCD4+ T-cell responses from a T helper 2 (Th2) to Th1 and regulatory T-cell profiles [9]. Few papers have been published concerning peach sublingual immunotherapy and none with the specific target of legume desensitization. In 2009, Pereira et al. described a LTPs-allergic patient who presented a negative double-blind placebo-controlled food challenge -acumulative dose of 150 grams of fresh peach-and a secondary good tolerance of legumes after four months of native Pru p3 specific sublingual immunotherapy with a maintenance dose of 200 $\mu \mathrm{g}$ of nPru p3 per month [10], similar to our monthly dose of $280 \mu \mathrm{g}$. One year later Garcia BE et al demonstrated changes in peach allergic patientsr Pru p3 IgE levels and in peach and apple extract SPT induced by a six month period of peach sublingual immunotherapy [11]. This study was not designed to evaluate legume sensitization.

Currently our patient tolerates all kinds of legumes, which he is recommended to ingest several times a week.

\section{References}

1. Pascual CY, Fernandez-Crespo J, Sanchez-Pastor S, Padial MA, Diaz-Pena JM, et al. (1999) Allergy to lentils in Mediterranean pediatric patients. J Allergy Clin Immunol 103: 154-158.
2. Vereda A, Andreae DA, Lin J, Shreffler WG, Ibañez MD, et al. (2010) Identification of IgE sequential epitopes of lentil (Len c 1) by means of peptide micro array immunoassay. J Allergy Clin Immunol 126: 596-601.

3. Akkerdaas J, Finkina EI, Balandin SV, Santos Magadán S, Knulst A, et al. (2012) Lentil (Lens culinaris) lipid transfer protein Len c 3: a novel legume allergen. Int Arch Allergy Immunol 157: 51-57.

4. Romano A, Fernandez-Rivas M, Caringi M, Amato S, Mistrello G, et al. (2009) Allergy to peanut lipid transfer protein (LTP): frequency and crossreactivity between peanut and peach LTP. Eur Ann Allergy Clin Immunol 41: 106-111.

5. Fernández-Rivas M, Garrido Fernández S, Nadal JA, Díaz de Durana MD, García BE, et al. (2009) Randomized double-blind, placebo-controlled trial of sublingual immunotherapy with a Pru p 3 quantified peach extract. Allergy 64: 876-883.

6. Orhan F, Karakas T (2008) Food-dependent exercise-induced anaphylaxis to lentil and anaphylaxis to chickpea in a 17 -year-old boy. J Investig Allergol Clin Immunol 18: 465-468.

7. Pascal M, Muñoz-Cano R, Reina Z, Palacín A, Vilella R, et al. (2012) Lipid transfer protein syndrome: clinical pattern, cofactor effect and profile of molecular sensitization to plant foods and pollens. Clin Exp Allergy 42: 1529-1539.

8. Letrán A, Espinazo M, Moreno F (2013) Measurement of IgE to pollen allergen components is helpful in selecting patients for immunotherapy. Ann Allergy Asthma Immunol 111: 295-297.

9. Novak N, Bieber T, Allam JP (2011) Immunological mechanisms of sublingual allergen-specific immunotherapy. Allergy 66: 733-739.

10. Pereira C, Bartolomé B, Asturias JA, Ibarrola I, Tavares B, et al. (2009) Specific sublingual immunotherapy with peach LTP (Pru p 3). One year treatment: a case report. Cases J 2: 6553.

11. García BE, González-Mancebo E, Barber D, Martín S, Tabar AI, et al. (2010) Sublingual immunotherapy in peach allergy: monitoring molecular sensitizations and reactivity to apple fruit and Platanus pollen. J Investig Allergol ClinI mmunol 2: 514-520. 